\title{
On-line monitoring of gene expression
}

\author{
Israel Biran, Levcov Klimentiy, Regine Hengge-Aronis, $†$ Eliora Z. Ron \\ and Judith Rishpon
}

\author{
Author for correspondence: Eliora Z. Ron. Tel: +972 3 6409379. Fax: + 97236414138 \\ e-mail: eliora $(a$ post.tau.ac.il
}

Department of Molecular Microbiology and Biotechnology, George S. Wise Faculty of Life Sciences, Tel-Aviv University, Tel-Aviv, Israel

\begin{abstract}
Gene expression in cultures of Escherichia coli has been determined in situ and on-line by the use of an electrochemical sensor. Intact bacteria were used to monitor the induction of the lacz gene; the onset of stationary phase was also monitored, using a reporter gene fused to the Rpos-dependent promoter of the osm $Y$ gene. The technique described can in principle be used to determine the activity of any promoter, with a variety of reporter genes. This technology is non-intrusive, allows real-time monitoring of gene expression, and will be useful in the study of growth regulation and development.
\end{abstract}

Keywords : biosensors, reporter gene, on-line monitoring, $\beta$-galactosidase

\section{INTRODUCTION}

Reporter-gene systems are frequently used in geneexpression studies. Various analytical methods are available for monitoring the protein expressed by a reporter gene, including photometry, radiometry, fluorescence, colorimetry and immunoassays (Alam \& Cook, 1990; Bronstein et al., 1994; Groskreutz \& Schenborn, 1997; Chalfie et al., 1994). The predominant methods used to identify and quantify reporter-gene products in cell cultures involve repeated samplings of the culture and an assay for the enzymic activity, which often involves an additional step of lysis or permeabilization of the cells. These procedures usually perturb the culture and are time consuming - they may take several hours. An alternative procedure, that would overcome several of these difficulties, is on-line monitoring for in situ determination of gene (or reporter gene) products. Such a system is especially advantageous in the study of developmental or growth-phase-related genes. Recently, several publications have described the possibility of using reporter genes such as lux or $g f p$ for on-line, or semi-on-line, non-invasive monitoring (Heitzer et al., 1994 ; Kodikara et al., 1991; Leibiger et al., 1998; Valdez et al., 1998).

This communication describes the development of a whole-cell biosensor for the on-line monitoring of gene expression. In the model system described, the determination was based on the electrochemical measurement of $\beta$-galactosidase activity, either expressed from

† Address: Institute of Plant Physiology \& Microbiology, Free University of Berlin, Berlin 14195, Germany.

Abbreviations: PAP, $p$-aminophenol; PAPG, $p$-aminophenyl $\beta$-D-galactopyranoside. its own promoter or as a reporter gene transcriptionally fused downstream of promoters of interest.

The gene lacZ, encoding the Escherichia coli enzyme $\beta$ galactosidase, is one of the most widely used reporter genes (Silhavy \& Beckwith, 1985). Standard assays are colorimetric (Miller, 1992), or use fluorimetry or chemiluminometry (Jain \& Magrath, 1991). All these methods involve the permeabilization of the cells followed by a multi-step procedure. An alternative to these is the use of electroanalytical methods that are suitable for on-line measurements, even in turbid solutions.

The activity of $\beta$-galactosidase can be determined electrochemically by using the substrate $p$-aminophenyl $\beta$-D-galactopyranoside (PAPG). The product of the enzymic reaction, $p$-aminophenol (PAP), can be oxidized at an electrode as shown in Fig. 1. The electrochemical characteristics of PAP and PAPG have been studied before (Kulys et al., 1980), and several electroanalytical methods for PAP detection have been reported (Kulys et al., 1980; Masson et al., 1995; Scott et al., 1997). In previous studies we developed a simple and sensitive electrochemical immunoassay, in which a constant potential is applied at the electrode and the current generated by the oxidation of PAP is measured (Rosen \& Rishpon, 1989). In the present study, this method was

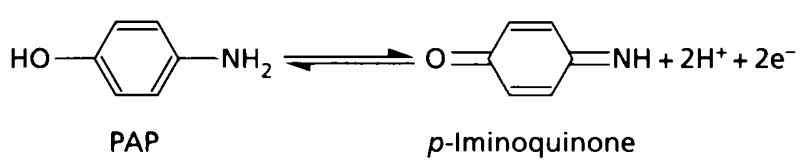

Fig. 1. Oxidation of PAP (the product of hydrolysis of PAPG, catalysed by $\beta$-galactosidase) to $p$-iminoquinone. 
adapted for the in situ and on-line monitoring of enzymes, such as $\beta$-galactosidase. As an example, we monitored on-line the progress of Escherichia coli into stationary phase, using transcriptional fusion of lac $Z$ to the RpoS-dependent osm Y gene (Weichart et al., 1993; Yim \& Villarejo, 1992).

\section{METHODS}

Bacterial strains and growth. E. coli $\mathrm{K}-12$ strain $\mathrm{K} 10$ (Hfr, tonA22 ompF626 relA1 pit-10 spoT1 T2 ${ }^{\mathrm{R}}$ CGSC [Coli Genetic Stock Center, New Haven, CT, USA] 4234) was from the CGSC collection. E. coli RO151 (MC4100 $\Phi(c s i-5:$ :lacZ) and E. coli RH99 (RO151 rpoS359:: Tn10) were described by Weichart et al. (1993). All cultures were grown aerobically at $37^{\circ} \mathrm{C}$ with vigorous shaking in LB medium (Miller, 1992), supplemented, when required, with $5 \mu \mathrm{g}$ tetracycline $\mathrm{ml}^{-1}$ or $25 \mu \mathrm{g}$ kanamycin $\mathrm{ml}^{-1}$.

Enzyme and chemicals. PAPG, isopropyl $\beta$-D-thiogalactopyranoside (IPTG) and $\beta$-galactosidase ( $\beta$-D-galactoside galactohydrolase; EC 3.2.1.23) were obtained from Sigma.

The amperometric assay. Electrochemical measurements were performed using a disposable three-electrode cell, based on a screen-printed electrode (total volume $0.3 \mathrm{ml}$ ). The electrochemical cells were made of polystyrene tubes (Fig. 2). Graphite ink was used as the counter electrode and $\mathrm{Ag} / \mathrm{AgCl}$ ink was used for the reference electrodes. Disposable graphite electrodes in cylindrical form (made from pencil leads, HB $0.9 \mathrm{~mm}$ ) were used as the working electrodes. The assay was performed directly in the electrochemical cells, which were vibrated to achieve mixing. The same screen-printed electrodes and graphite working electrode were also used for direct measurements in cultures. In this case the electrodes were placed inside the Erlenmeyer flask as shown in Fig. 2 and mixing was achieved by bubbling air. The graphite electrode was held at $220 \mathrm{mV}$ versus the reference electrode and the substrate (PAPG) concentration was $0.4 \mathrm{mg} \mathrm{ml}^{-1}$.

The experimental setup. The electrochemical measurements were performed using a PAR VersaStat potentiostat connected to an 8-channel PAR 314 model multiplexer (EG\&G Princeton Applied Research). This system allows simultaneous measurements of eight samples with disposable electrochemical cells. The measurements were controlled by LAbVIEW-based software using a Windows 95 operating system. The electrical current from the activity of $\beta$-galactosidase was visualized simultaneously in all eight samples in real-time on the computer screen (see Figs 3 and 4).

\section{RESULTS}

\section{Configuration and optimization of the $\beta$-galactosidase amperometric monitoring system}

A multiple-cell electrochemical device was used to optimize the detection of $\beta$-galactosidase activity. The

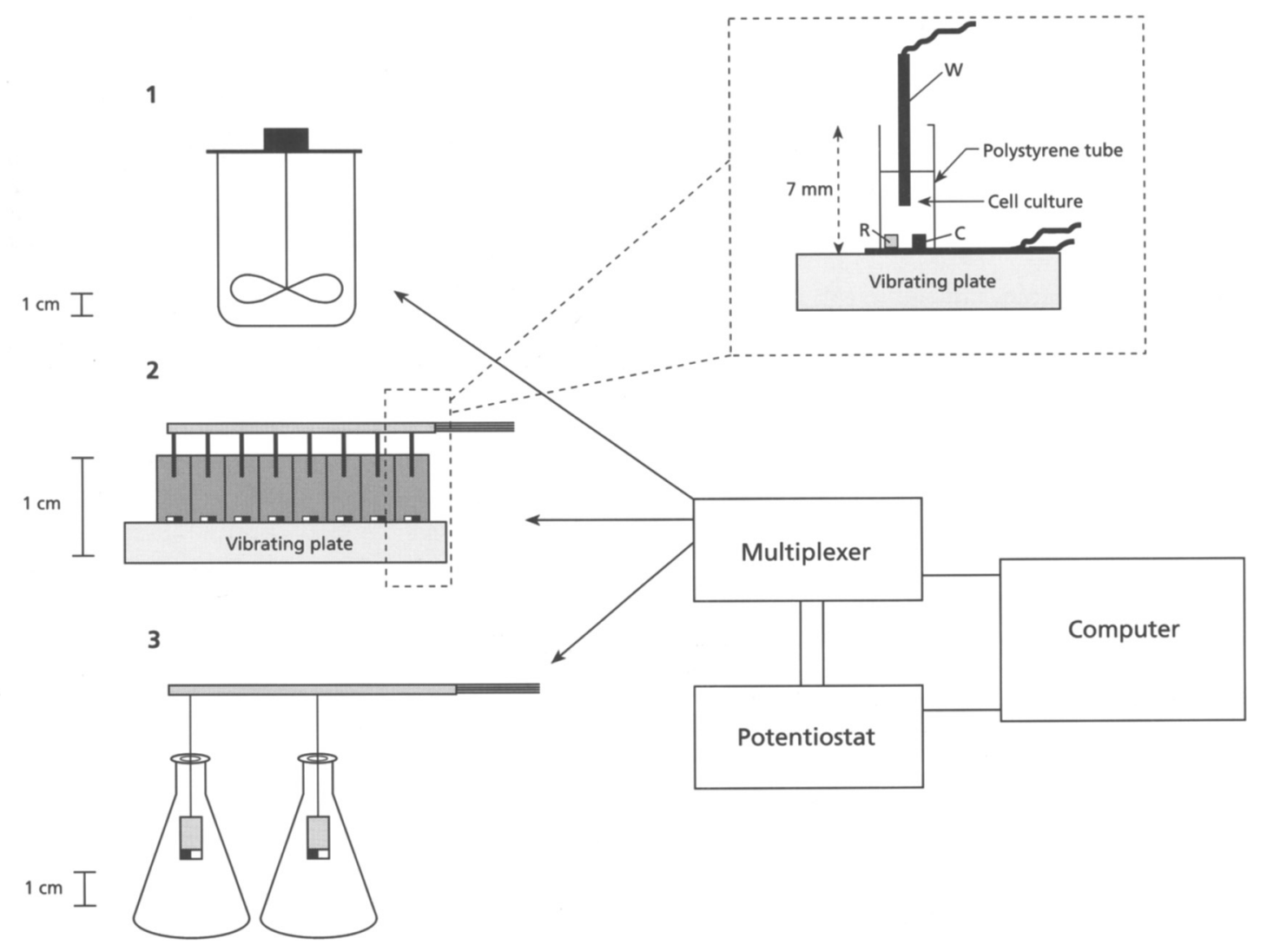

Fig. 2. The computerized electrochemical system. The electrochemical device is connected to a multiplexer and can be used for on-line monitoring in a fermenter (1), in multiple cells (volume $0.3 \mathrm{ml}$; eight electrodes are shown) (2), or directly in flasks (3). The electrodes used were disposable and sterilizable. The measurements were controlled by LAbVIEW-based software using a Windows 95 operating system. (Inset: electrochemical cell. W, working electrode; C, counter electrode; $R$, reference electrode.) 
(a)

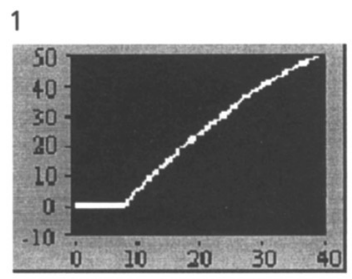

2

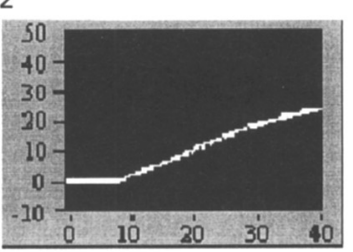

3

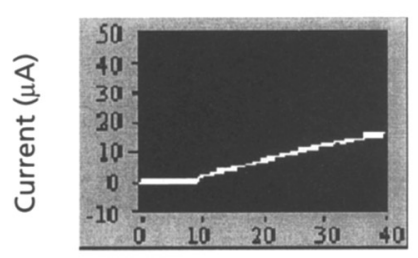

5

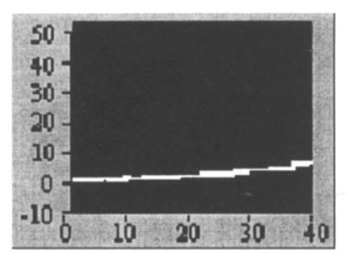

4

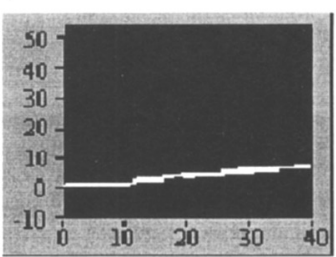

6

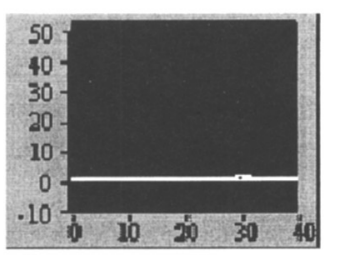

Time (s)

(b)

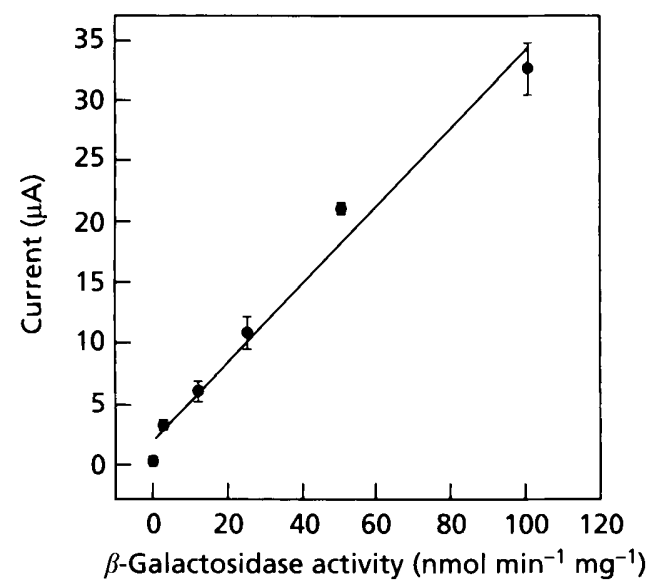

Fig. 3. On-line monitoring of $\beta$-galactosidase using the multiple-cell electrochemical device. The graphite electrode was held at $220 \mathrm{mV}$ versus the reference electrode and the enzyme concentrations, in $0.1 \mathrm{M}$ phosphate buffer containing 0.4 unit $\mathrm{ml}^{-1}$ PAPG and $1 \mathrm{mM} \mathrm{MgCl}$, were: (1) 100 units $\mathrm{ml}^{-1}$, (2) 50 units $\mathrm{ml}^{-1}$, (3) 25 units $\mathrm{ml}^{-1}$, (4) 12 units $\mathrm{ml}^{-1}$, (5) 6 units $\mathrm{ml}^{-1}$ (6) no enzyme. (a) On-screen data; the current scales run from -10 to $+50 \mu \mathrm{A}$ and the time scales from 0 to $40 \mathrm{~s}$. (b) Calibration curve calculated from the current obtained $10 \mathrm{~s}$ (lag time in the system) after the addition of the substrate.

results presented in Fig. 3(a) demonstrate the use of the multiple-cell device for determining the activity of purified $\beta$-galactosidase, using PAPG as a substrate. The results are presented as visualized on the computer

(a)

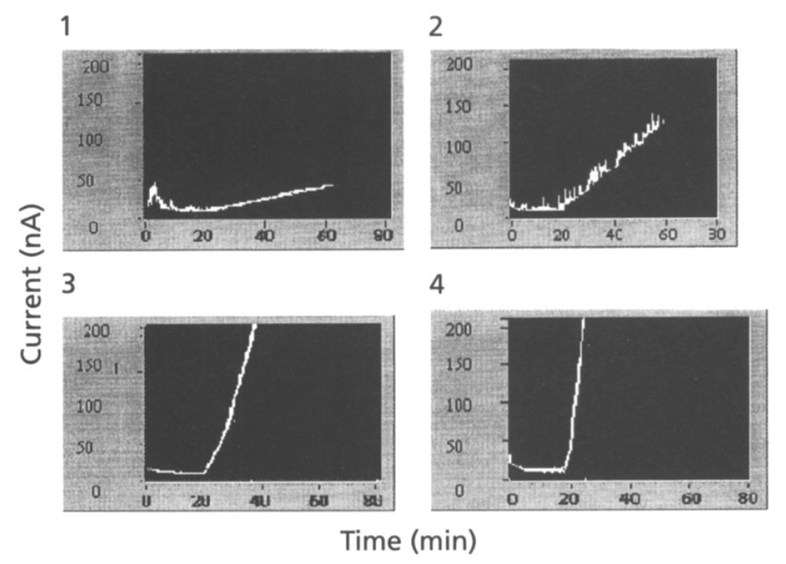

(b)

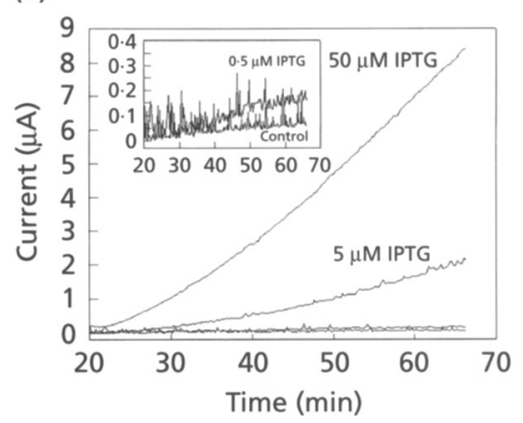

Fig. 4. $\beta$-Galactosidase activity of $E$. coli cultures treated with increasing concentrations of IPTG. The cells were grown in LB medium at $37^{\circ} \mathrm{C}$ to a density of about $2 \times 10^{8}$ bacteria $\mathrm{ml}^{-1}$. Samples of $0.3 \mathrm{ml}$ were introduced in duplicate to the eight electrochemical cells. The inducer [(1) no IPTG, (2) $0.5 \mu \mathrm{M}$ IPTG (3) $5 \mu \mathrm{M}$ IPTG, (4) $50 \mu \mathrm{M}$ IPTG] was added and monitoring started after $20 \mathrm{~min}$ with the addition of 0.4 unit $\mathrm{ml}^{-1}$ of the substrate (PAPG). (a) On-screen display of the data obtained from four electrochemical cells; the current scales run from 0 to $200 \mathrm{nA}$ and the time scales from 0 to $80 \mathrm{~min}$. (b) Curves of mean signal from duplicate samples.

screen and represent the signals from the enzymic reaction in six electrochemical cells containing increasing concentrations of the enzyme. In the calibration plot constructed from these and additional data (Fig. 3b), a linear correlation was observed in the range 3-100 units $\mathrm{ml}^{-1}$ and the detection limit was 1 unit $\beta$-galactosidase $\mathrm{ml}^{-1}$.

\section{On-line monitoring of $\boldsymbol{\beta}$-galactosidase in intact bacteria}

For many purposes it is preferable to monitor gene expression on-line. The electroanalytical assays are potentially suitable for such determinations, as they do not require permeabilization of the cells and are rapid and sensitive. To assess whether the electroanalytical assay for $\beta$-galactosidase, the lac $Z$ reporter gene product, could be successfully adapted for on-line monitoring, we determined the enzymic activity following induction with IPTG. Increasing concentrations of the inducer were added to cultures of E. coli K10 (Annette \& 


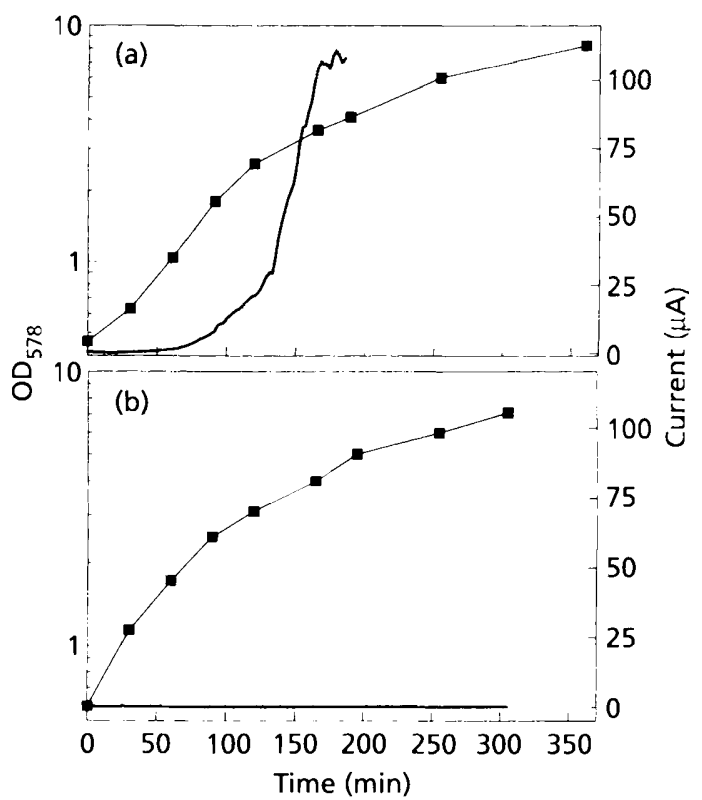

Fig. 5. On-line amperometric monitoring of the expression of the osm Y-lacZ gene fusion in (a) E. coli RO151 (rpos') and (b) rpoS mutant $E$. coli RH99 (rpoS359::Tn10). Optical density (squares) and amperometric monitoring (line without symbols) of $\beta$-galactosidase, determined in cultures growing in LB medium at $37^{\circ} \mathrm{C}$. The substrate PAPG was added at the beginning of the experiment and the graphite electrode was held at $220 \mathrm{mV}$ versus the reference electrode.

Anthony, 1987) and the current signal was monitored on-line in all the cultures simultaneously (Fig. 4a). The slope of the current signals with time was proportional to the concentrations of IPTG added (from $0.5 \mu \mathrm{M}$ IPTG) (Fig. 4b).

\section{Monitoring the onset of stationary phase in $E$. coli}

As a model for monitoring gene expression we used $E$. coli carrying a chromosomal lac $Z$ fusion to the osm $Y$ promoter, which is positively regulated by the transcription factor $\operatorname{RpoS}\left\langle\sigma^{\star}\right\rangle$ and is therefore expressed only at the stationary phase (Weichart et al., 1993; Yim \& Villarejo, 1992). As a control we used an isogenic strain which carries an interruption of the rpos gene (Weichart et al., 1993). In this experiment the screenprinted electrodes and graphite working electrode were placed inside the Erlenmeyer flask (see Fig. 2) and the expression of lac $Z$ was continuously measured. As shown in Fig. 5(a), a significant increase in the current signal was obtained in the transition to stationary phase. In parallel we examined the reporter gene in an rpoS mutant strain, where the signal was not obtained (Fig. 5 b). These results are in agreement with previous results obtained with a colorimetric assay (Weichart et al., 1993).

\section{DISCUSSION}

This paper describes the use of a new electroanalytical device for on-line and in situ monitoring of gene expression. The on-line monitoring is facilitated by the ability to determine the enzymic activity in whole cells with no need for sample removal or changing the permeability of the cells. The in situ assay renders kinetic analysis of gene expression more convenient and accurate. Only a single sample of bacteria is needed to derive the time course of transcriptional activity of a gene and its response to transcriptional or environmental modulators. Moreover, the simultaneous monitoring allows a precise comparison of several strains or experimental conditions.

The on-line, in situ, amperometric monitoring of enzyme activity can be used to determine the expression of a variety of genes, as current molccular procedures facilitate the fusion of a variety of reporter genes to a limitless variety of promoters. One interesting application would be to monitor the expression of secreted proteins - periplasmic or extracellular - using fusion to reporter proteins such as chloramphenicol acetyltransferase or alkaline phosphatase (Manoil et al., 1990), that are active only when secreted. The determination of a secreted protein would be even more sensitive than that of a cytoplasmic protein. An adaptation of our system for the use of alkaline phosphatase requires only minor modifications, since the same compound-PAP - is the product of both reactions. For other reporter genes the required modifications involve only identification of suitable substrates, but no alteration in the equipment.

Although it is conceivable to adapt other reporter genes, such as lux and $g f p$, for on-line or semi-on-line monitoring (Heitzer et al., 1994; Kodikara et al., 1991; Leibiger et al., 1998; Valdez et al., 1998), the amperometric biosensor reported here has several advantages. These include high sensitivity, simplicity, and the fact that the electrodes are disposable. Moreover the electrochemical reaction can be performed even in turbid solutions and under anaerobic conditions.

Whole-cell biosensors of the type described here can be developed for monitoring various aspects of growth and gene expression in prokaryotic and eukaryotic cells. This system is potentially useful for other on-line applications and can be applied to micro-organisms as well as for cell cultures. The potential uses include monitoring the availability of a nutrient in a fermenter, production of a protein of interest - natural or recombinant - and monitoring transfection efficiency in cell cultures (Hollon \& Yoshimura, 1989). On-line monitoring of gene activity will be particularly useful for biotechnological applications, such as fermentation processes, where the exact state of the culture at any given time, and especially the concentration of the required fermentation product, are important parameters.

\section{ACKNOWLEDGEMENTS}

This work was supported, in part, by the Kurt-Lion Foundation, by the Fonds der Chemische Industrie, and by the Manja and Morris Leigh Chair for Biophysics and Biotechnology. 


\section{REFERENCES}

Alam, J. \& Cook, J. L. (1990). Reporter genes: application to the study of mammalian transcription. Anal Biochem 188, 245-254.

Annette, T. L. \& Anthony, C. (1987). Elevated glucose 6phosphate levels are associated with plasmid mutations in vivo. Proc Natl Acad Sci USA 84, 8311-8314.

Bronstein, I., Fortin, J., Stanley, P. E., Stewart, G. S. A. B. \& Kricka, L. J. (1994). Chemiluminescent and bioluminescent gene assays. Anal Biochem 219, 169-181.

Chalfie, M., Tu, Y., Euskirchen, G., Ward, W. W. \& Prasher, D. C. (1994). Green fluorescence protein as a marker for gene expression. Science 263, 802-805.

Groskreutz, D. \& Schenborn, E. T. (1997). Reporter systems. Methods Mol Biol 63, 11-30.

Heitzer, A., Malachowsky, K., Thonnard, J. E., Bienkowski, P. R., White, D. C. \& Sayler, G. S. (1994). Optical biosensor for environmental on-line monitoring of naphthalene and salicylate bioavailability with an immobilized bioluminescent catabolic reporter bacterium. Appl Environ Microbiol 60, 1487-1494.

Hollon, T. \& Yoshimura, F. K. (1989). Variation in enzymatic transient gene expression assays. Anal Biochem 182, 411-418.

Jain, V. K. \& Magrath, I. T. (1991). A chemiluminescent assay for quantitation of $\beta$-galactosidase in the femtogram range: application to quantitation of $\beta$-galactosidase in lac $Z$-transfected cells. Anal Biochem 199, 119-124.

Kodikara, C. P., Crew, H. H. \& Stewart, G. S. (1991). Near on-line detection of enteric bacteria using lux recombinant bacteriophage. FEMS Microbiol Lett 67, 261-265.

Kulys, J., Razumas, V. \& Malinauskas, A. (1980). Electrochemical oxidation of catechol and $p$-aminophenol esters in the presence of hydrolase. J Electroanal Chem [Bioelectrochem Bioenerg 7] 116, 11-24.

Leibiger, I. B., Leibiger, B., Moede, T. \& Berggren, P.-O. (1998).
Exocytosis of insulin promotes insulin gene transcription via the insulin receptor PI-3 kinase p70 s6 kinase and CaM kinase pathways. Mol Cell 1, 933-938.

Manoil, C., Mekalanos, J. J. \& Beckwith, J. R. (1990). Alkaline phosphatase fusion: sensor for subcellular location. J Bacteriol 172, 515-518.

Masson, M., Liu, Z., Haruyama, T., Kobatake, E., Ikariyama, Y. \& Aizawa, M. (1995). Immunosensing with amperometric detection, using galactosidase as label and $p$-aminophenyl- $\beta$-D-galactopyranoside as substrate. Anal Chim Acta 304, 353-359.

Miller, J. H. (1992). A Short Course in Bacterial Genetics, pp. 72-74. Cold Spring Harbor, NY: Cold Spring Harbor Laboratory.

Rosen, I. \& Rishpon, J. (1989). Alkaline phosphatase as a label for hetrogeneous immunoelectrochemical sensor. J Electroanal Chem 258, 27-39.

Scott, D. L., Ramanathan, S., Shi, W., Rosen, B. P. \& Daunert, S. (1997). Genetically engineered bacteria: electrochemical sensing system for antimonite and arsenite. Anal Chem 69, 16-20.

Silhavy, T. J. \& Beckwith, J. R. (1985). Uses of lac fusions for the study of biological problems. Microbiol Rev 49, 398-418.

Valdez, B. C., Perlaky, L., Cai, Z. J., Henning, D. \& Busch, H. (1998). Green fluorescent protein tag for studies of drug-induced translocation of nucleolar protein $\mathrm{RH}-\mathrm{Il} / \mathrm{Gu}$. Biotechniques 24, 1032-1036.

Weichart, D., Lang, R., Henneberg, N. \& Hengge-Aronis, R. (1993). Identification and characterization of stationary phase-inducible genes in Escherichia coli. Mol Microbiol 10, 407-420.

Yim, H. H. \& Villarejo, M. (1992). Osm Y, a new hyperosmotically inducible gene, encodes a periplasmic protein in Escherichia coli. J Bacteriol 174, 3637-3644.

Received 12 January 1999; revised 8 April 1999; accepted 21 April 1999. 